\title{
Impact of Social Distancing on COVID-19 and Other Related Infectious Disease Transmission: A Systematic Review
}

\author{
Nor Rumaizah Mohd $\operatorname{Nordin}^{1}$, Fadly Syah Arsad ${ }^{1}$ D, Puteri Sofia Nadira Megat Kamaruddin ${ }^{1}$ (D), Muhammad Hilmi ${ }^{1}$ (D) \\ Mohd Faizal Madrim ${ }^{2}$ (D), Mohd Rohaizat Hassan ${ }^{1}$ (D), Syed Sharizman Syed Abdul Rahim ${ }^{2 *}$ (i), Mohammad Saffree Jeffree ${ }^{2}$, \\ Abdul Rahman Ramdzan² (i), Azman Atil ${ }^{2}$ (i) , Khalid Mokti ${ }^{2}$ (D) Muhammad Aklil Abd. Rahim² ${ }^{2}$, Zulkhairul Naim Bin SidekAhmad² \\ ${ }^{1}$ Department of Community Health, Faculty of Medicine, Universiti Kebangsaan Malaysia, Bandar Tun Razak, Kuala Lumpur, \\ Malaysia; '² Department of Public Health Medicine, Faculty of Medicine and Health Sciences, Universiti Malaysia Sabah, Kota \\ Kinabalu, Sabah, Malaysia
}

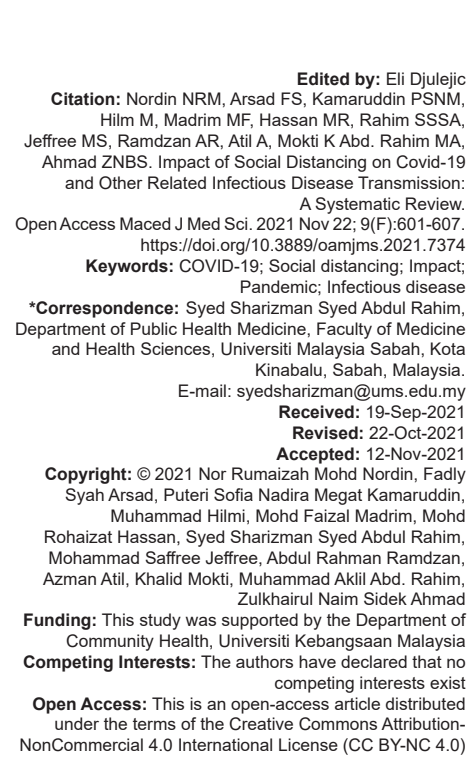

Introduction

2019 novel coronavirus (severe acute respiratory syndrome [SARS]-CoV-2) which causes the disease COVID-19 was first identified in December 2019 [1]. Similar to other coronaviruses, SARS-CoV-2 is transmitted mainly by droplets [2] and is highly transmissible through close proximity or physical contact with an infected person [3], [4]. Without an effective vaccine or treatment, countries across the globe have implemented public health and physical measures to prevent onward transmission and reduce burden on health care settings [5]. These include increased hygiene measures, such as hand washing and respiratory etiquette; travel restrictions and related measures, including border closures and quarantining of people returning from overseas; and physical distancing. Physical distancing measures apply to both individuals and the community, through restrictions on mass gatherings, restriction in day care centers, closure of schools, workplaces, and public spaces, and recommendations for keeping at least

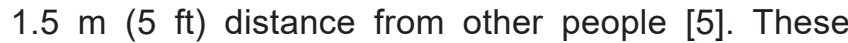
acts were based on the best evidence available at the time of the introduction. The evidence consisted of global experience and previous pandemics [6]. In some studies, social distancing reduced the spreading of seasonal influenza in workplaces [7]. The real effect of these broad restrictions on the spreading of diseases is not known, but it appeared to decrease the spreading of the novel coronavirus in China in 2020 [8]. In Japan, the influenza season in 2020 was shorter than normal possibly because of the physical distancing [9]. Physical distancing due to COVID-19 also reduces opportunities for all close contact with 
others, including for sexual and physical intimacy. The disruption of sexual contacts operates at both an interpersonal and network level, therefore reducing opportunities for sexually transmissible pathogens to spread [10]. This review aims to seek new evidence of social or physical distancing impact as a control measure during this COVID-19 pandemic, and thus new era of globalization toward disease transmission of COVID-19 itself and also other related infectious diseases.

\section{Methodology}

\section{Literature review}

A systematic review of the literature was conducted to identify relevant studies about the impact of social distancing toward COVID-19 transmission. To conduct a comprehensive search of health science journals, we used Ovid MEDLINE and Scopus databases with no limited timeframe since this is a recent topic. The search strategy involved a combination of the following two sets of key words and identified Medical Subject Heading terms for: (1) COVID-19 OR SARSCoV-2 OR 2019-nCov OR 2019 novel coronavirus OR coronavirus disease 2019 OR coronavirus disease-19 AND (2) social distancing OR physical distancing OR physical distance. All search stopped on $25^{\text {th }}$ December 2020 with a total of 1565 records.

\section{Selection of research articles}

The results were limited to studies that were published in English language with included abstracts. Studies with these characteristics were included in this review: (1) report on the impact of social distancing to COVID-19 transmission; and (2) report on the impact of social distancing to other infectious diseases which we decided to include to analyze on how social distancing as control measures also affect other infectious diseases. Systematic review, narrative review articles, news, letter, editorials, or case studies were excluded from this review.

\section{Data extraction and management}

Duplicates were removed and the remaining papers were re-screened by at least two reviewers. Articles were screened in three phases before included in the review. In the first phase, any paper that did not match the inclusion criteria from title screening was excluded. In the second phase, abstracts of the remaining papers were assessed and paper that did not meet our inclusion criteria was excluded from this review. In the final phase, the full-text articles were read thoroughly to exclude any paper that did not meet our inclusion criteria. Both reviewers must agree that the full papers should be in the review before the data extraction phase. Any differences in opinions were resolved through discussion. All data extraction was performed independently with a standardized and customized data collection table (Appendix A). The following data were recorded: (1) type of study (2) type of infectious disease involve in the study; (3) sample/ population of the study; (4) methods; (5) results; (6) comments and conclusion of the study.

\section{Quality appraisal}

The final list of studies was ranked for quality according to the Mixed Method Appraisal Tool (MMAT) [11] to ensure the quality of the articles to be reviewed by exploring in detail how the data were extracted for analysis and validation. The MMAT is a developed tool that has demonstrated an intra-class correlation of 0.8 based on a pilot testing in 2009 and has proven to be effective and practical for the quality assessment of a mixed methods review [11]. We performed qualitative analysis and appraisal of the included articles by extracting all relevant information using a predesigned, standardized data extraction form [11]. The MMAT quality scoring scale are scored as Yes (20\%), Unsure (10\%) and No (0\%) for each criterion. The details of this assessment are reported in Appendix B. Overall, scores of the MMAT vary from $70 \%$ (three criteria met) to $100 \%$ (all criteria met). One author in the team crosschecked the results of the assessment with disagreement resolved via discussion leading to a consensus.

\section{Results}

We retrieved 1565 unique citations through our electronic databases search to evaluate the social distancing outcomes in the midst of COVID-19 pandemic. Before titles and abstracts screening, 1319 duplicate articles were removed. A total of 1319 titles and abstracts were screened based on the eligibility criteria of which 1286 were excluded based on irrelevant studied population, intervention characteristics or outcomes. 33 full text articles were then screened for eligibility of which 25 articles were excluded as they are not according to the main objective of social distancing impact towards the transmission of COVID-19 or other infectious diseases. Subsequently, 8 articles remained to be included in the review. Our search PRISMA flowchart is presented in Figure 1.

\section{Study characteristics}

A total of 8 studies were included in this analysis (Appendix A). These studies were conducted 


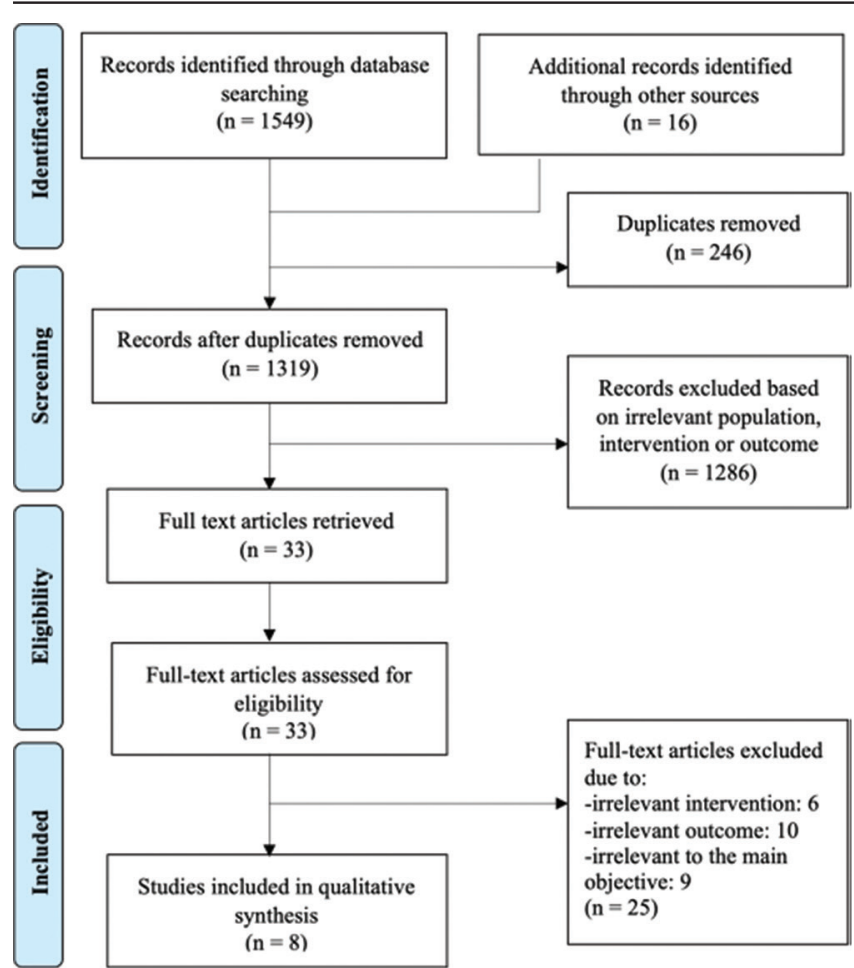

Figure 1: PRISMA flowchart of social distancing impact toward the transmission of COVID-19 or other infectious diseases

globally from United Kingdom [12], Canada [13], America [14], [15], South Korea [16], [17], Australia [18], and Finland [19]. The themes discussed by all studies were the impact of social distancing as a control measure of COVID-19 pandemic toward COVID-19 cases, also on other infectious disease trends. 5 types of study are looking at COVID-19 patterns, namely, time series analysis, modeling study, cohort, and two cross-sectional studies [12], [13], [14], [15], [16]. While other infectious diseases, such as Human Immunodeficiency Virus (HIV), other sexual transmitted diseases, influenza, respiratory syncytial virus (RSV), and VaccinePreventive Disease (VPD) are being observed through cohort and cross-sectional studies [17], [18], [19]. There is one multi-country study and two multicounties study that were conducted to get the overall pattern [12], [14], [15] as compared to the rest of the studies which conducted in only one country or locality [13], [16], [17], [18], [19]. The resultant effect of social distancing can be seen on the general population from five studies [12], [13], [14], [15], [17], while three studies were focussing on the sample population among workplace cases (e.g., workers, customers, patients, and students), gay/bisexual and children [16], [18].

\section{Social distancing impact toward COVID-19}

To define the independent variable which are the social distancing or physical distancing, five studies generally used the government policy of distancing that was applied during the pandemic while two studies actually measured or define the distancing through daily cellular telephone movement and data [14], [15].
The impact toward COVID-19 transmission (dependent variable) where measured by assessing the pre and post social or physical distancing intervention incidence rate ratios, attack rate, instantaneous reproduction rate (Rt), incidence rates, and number of cases of COVID-19. Conclusively, all eight studies show social or physical distancing is effective in reducing the transmission of COVID-19 (Appendix A).

\section{Social distancing impact toward other infectious diseases}

Other infectious diseases were found to be decreasing in trend along with COVID-19 through social distancing measures. For example, drop in HIV incidences were from reduced sexual contacts, common respiratory viral diseases were noted decreasing from less pediatric emergency department (ER) visits, shorter influenza season and decline in RSV [18] and VPD cases [17] (Appendix A).

\section{Types of social distancing or physical distancing policy applied}

Three studies involve a stricter general distancing policy that has been enforced in most countries globally such as closure of school and workplaces, restrictions of mass gatherings, $1.5 \mathrm{~m}$ distance from other people, public transport closures and lock down which involve stay at home regulations and restriction of movements within a country [12], [18]. Study in Canada [13] define social or physical distancing more specific which is reducing number of contacts per day (outside of the household), similar with two studies in the US which one [14] define it as percentage change in visits to non-essential business and the other is more elaborate which are daily distance difference of travelling, daily visitation to non-essential business and daily human encounter in $50 \mathrm{~m}$ or less[15]. On the other hand, South Korea studies focus on distancing guideline at workplace which are flexible working system, vacation system, minimizing meetings and business trips, case monitoring (temperature and suspicious symptoms), space management (keep $2 \mathrm{~m}$ distance from each other), hygiene, disinfection and cleanliness [16]. Finally, another study in South Korea defines their distancing on general population as no draconian restriction of movement; it is either voluntary based or administrative sanction based actions according to infection control policies and guideline [17].

\section{Discussion}

Physical and social distancing strategies vary according to countries during this COVID-19 
pandemic. Some countries opted for far stricter almost draconian distancing policy while others are not and depend much on individual or organization or company following administration of infection policy and guideline. Previously, these measure of restricting movement of population proven to be highly effective in preventing spread of contagious disease, for example the transmission of SARS which focused more on isolation and quarantine implementation with other distancing policy applied were far more lenient, less elaborate compared to the current policy for COVID-19 that could be due to the much smaller scale of transmission of SARS [19]. The aim of social or physical distancing during COVID-19 is to reduce transmission rate of COVID-19, hence maintain flatten the curve which allow healthcare system to prepare adequately if needed [20]. This review showed that stricter restriction for example total closure of school, workplace and other premises, stay at home enforcement with border closure (domestic and internationally) within a country shows significant impact in reducing COVID-19 transmission [12], [21]. The finding is supported by the recent study, which concluded that social distancing with mask use and city yields a positive impact specifically in reducing daily new cases of COVID-19 [22]. At the other end, we also have countries that have applied more lenient method of distancing policy, such as gathering allowed with workplace, schools, premises remained open according to infection policy, and distancing guideline [16], [17]. Despite the leniency and much depend on individual responsibility and voluntarism, they are still able to reduce transmission rate. Stricter distancing policy or lockdowns that place severe limitations on individual movement and group gathering, closing border and restriction on domestic and international travel came with extra baggage of economic, mental health, and education impact with increase of morbidity and mortality form non-COVID19 diseases [22]. Looking at the effectiveness of both lenient and strict distancing policy, "Precision physical distancing" can be used which is distancing policy tailored and optimized to specific physical, social, cultural, political and economics contexts and to specific groups and settings [22]. Compared to strict or draconian restriction, this method can be one of sustainable longterm solution, that gives both good effect to transmission rates and socioeconomic, allowing partial return to activities with community as trusted and empowered essential partner. Distancing policies also affect other infectious diseases such as HIV, STD, influenza, RSV and VPD which is great news however need to consider the rights of people to have sexual connection with their partner that could affect their quality of life and mental health. Furthermore, there is the possibility of severe case of non-COVID-19 infectious diseases undertreated because patient not seeking appropriate treatment due to COVID-19 scare and strict distancing order thus contributing the low cases detected at hospital or ER.

\section{Conclusion}

Physical or social distancing may come in the form of extreme or lenient measure in effectively containing contagious disease such as COVID-19, however the stricter the measure will give more proportionate impact toward the economy, education, mental health issues, morbidity and mortality of nonCOVID-19 diseases. Since we need this measure to ensure the reduction of infectious diseases transmission to help flattening the curve which allow much needed time for healthcare system to prepare adequately to response, "Precision physical distancing" can be implemented which will have more benefit toward the survival of the community as a whole.

\section{Acknowledgments}

This study is supported by the Department of Community Health, Universiti Kebangsaan Malaysia (UKM). This publication reflects the views of the authors only and UKM cannot be held liable for any use made of the information contained therein.

\section{Author Contributions}

All authors contributed to the design and implementation of the research, analysis of the results and writing of the manuscript.

\section{References}

1. Bray F, Ferlay J, Soerjomataram I, Siegel RL, Torre LA Jemal A. Global cancer statistics 2018: GLOBOCAN estimates of incidence and mortality worldwide for 36 cancers in 185 countries. CA Cancer J Clin. 2018;68(6):394-424. http://doi. org/10.3322/caac.21492

PMid:30207593

2. Cardona CE, García-Perdomo HA, Cardona CE, García-Perdomo HA. Incidence of penile cancer worldwide: Systematic review and meta-analysis. Rev Panam Salud Pública. 2018;41:e117

PMid:31384255

3. Cubilla AL, Amin MB, Ayala A, Ayala G, Chaux A, Corbishley C Tumours of the penis, malignant epithelial tumours. In: WHO Clasification of Tumours of the Urinary System and Male Genital Organs; 2016. p. 263

4. Vieira $\mathrm{CB}$, Feitoza L, Pinho J, Teixeira-Júnior A, Lages J, Calixto J, et al. Profile of patients with penile cancer in the region with the highest worldwide incidence. Sci Rep. 2020;10(1):2965. 
http://doi.org/10.1038/s41598-020-59831-5

PMid:32076037

5. Lagacé F, Ghazawi FM, Le M, Savin E, Zubarev A, Powell M, et al. Penile invasive squamous cell carcinoma: analysis of incidence, mortality trends, and geographic distribution in Canada. J Cutan Med Surg. 2020;24(2):124-8. http://doi. org/10.1177/1203475419888869

PMid:31722549

6. Korkes F, Rodrigues AF, Baccaglini W, Cunha FT, Slongo J, Spiess $\mathrm{P}$, et al. Penile cancer trends and economic burden in the Brazilian public health system. Einstein (São Paulo). 2020;18:eAO5577. http://doi.org/10.31744/ einstein_journal/2020AO5577

PMid:33174969

7. Hernandez BY, Barnholtz-Sloan J, German RR, Giuliano A, Goodman MT, King JB, et al. Burden of invasive squamous cell carcinoma of the penis in the United States, 1998-2003. Cancer. 2008;113(Suppl 10):2883-91. http://doi.org/10.1002/cncr.23743 PMid:18980292

8. Lestari DP, Armerinayanti NW, Lestari D, Armerinayanti N, Lestari DP, Armerinayanti NW. Increasing trend of penile cancer cases in Bali compared to other regions in Indonesia. IOP Conf Ser Mater Sci Eng 2018;434:8.

9. de Cássio Zequi S, Guimarães GC, da Fonseca FP, Ferreira U, de Matheus WE, Reis LO, et al. Sex with animals (SWA): behavioral characteristics and possible association with penile cancer. A multicenter study. J Sex Med. 2012;9(7):1860-7. http://doi.org/10.1111/j.1743-6109.2011.02512.x PMid:22023719

10. Kristiansen S, Bjartling C, Svensson A, Forslund O, Torbrand C. Penile intraepithelial neoplasia, penile cancer precursors and human papillomavirus prevalence in symptomatic preputium: A cross-sectional study of 351 circumcised men in Sweden. BJU Int. 2021;127(4):428-34. http://doi.org/10.1111/bju.15221 PMid:32870593

11. Douglawi A. Updates on the epidemiology and risk factors for penile cancer. Transl Androl Urol 2017;6(5):785-90. http://doi. org/10.21037/tau.2017.05.19 PMid:29184774

12. Hakenberg OW, Compérat EM, Minhas S, Necchi A, Protzel C, Watkin N. EAU guidelines on penile cancer: 2014 update. Eur Urol. 2015;67(1):142-50. https://doi.org/10.1016/j. eururo.2014.10.017

\section{PMid:25457021}

13. de Medeiros PF Jr., Silva EH, Moura KL, de Aquino YF, Weller $\mathrm{M}$. Increased risk of penile cancer among men working in agriculture. Asian Pac J Cancer Prev. 2018;19(1):237-41. http:// doi.org/10.22034/APJCP.2018.19.1.237

PMid:29374407

14. Kusmawan E, Bowolaksono WR, Widiana R. The clinical features of penile cancer patients at sanglah general hospital Bali-Indonesia. Bali Med J. 2012;1(1):1-5.

15. Kirrander P. Swedish national penile cancer register: Incidence, tumour characteristics, management and survival. BJU Int. 2016;117(2):287-92. http://doi.org/10.1111/bju.12993 PMid:25395083

16. Cubilla AL. Pathology and Genetic, Tumours of the Urinary System and Male Genital Organs. Lyon: IARC Press; 2004. p. 281-90.

17. Gajalakshmi CK, Shanta V. Association between cervica and penile cancers in Madras, India. Acta Oncol (Madr). 1993;32(6):617-20. http://doi.org/10.3109/02841869309092439 PMid:8260177

18. Olesen TB, Sand FL, Rasmussen CL, Albieri V, Toft BG, Norrild B, et al. Prevalence of human papillomavirus DNA and p16INK4a in penile cancer and penile intraepithelial neoplasia: A systematic review and meta-analysis. Lancet Oncol 2019;20(1):145-58. http://doi.org/10.1016/S1470-2045(18)30682-X PMid:30573285

19. Lestari DP, Dewi SR, Armerinayanti NW. Strengthening the role of cadres and village midwives to support the cervical cancer awareness movement in Puhu Payangan village, Gianyar Bali, Indonesia. Indones J Community Engagem. 2021;7(1):41.

20. Maden C, Sherman KJ, Beckmann AM, Hislop TG, The CZ, Ashley RL, et al. History of circumcision, medical conditions, and sexual activity and risk of penile cancer. J Natl Cancer Inst. 1993;85(1):19-24. http://doi.org/10.1093/jnci/85.1.19 PMid:8380060

21. Ornellas AA, Ornellas P. Should routine neonatal circumcision be a police to prevent penile cancer? Opinion: Yes. Int Braz $\mathrm{J}$ Urol. 2017;43(1):7-9.

22. Larke NL. Male circumcision and penile cancer: A systematic review and meta-analysis. Cancer Causes Control. 2011;22(8):1097-110. http://doi.org/10.1007/s10552-011-9785-9 PMid:21695385 


\section{Appendix}

Appendix A: Characteristics of studies included in this review

\begin{tabular}{|c|c|c|c|c|c|}
\hline Author/year & $\begin{array}{l}\text { Type of study/type of } \\
\text { infectious disease }\end{array}$ & Sample/population & Methodology & $\begin{array}{l}\text { Types of social distancing/ } \\
\text { physical distancing }\end{array}$ & Results \\
\hline $\begin{array}{l}\text { Islam et al., } \\
2020\end{array}$ & $\begin{array}{l}\text { Time series analysis/ } \\
\text { COVID-19 }\end{array}$ & $\begin{array}{l}149 \text { countries/ } \\
\text { conducted in United } \\
\text { Kingdom/General } \\
\text { population }\end{array}$ & $\begin{array}{l}\text { Comparison of COVID-19 } \\
\text { incidence rate before and after } \\
\text { implementation of physical } \\
\text { distancing intervention or } \\
\text { interventions. Conducted on data } \\
\text { from } 1^{\text {st }} \text { January to May } 30,2020\end{array}$ & $\begin{array}{l}\text { Closure of schools and } \\
\text { workplaces, restrictions of } \\
\text { mass gatherings (public } \\
\text { events and restrictions } \\
\text { to gathering), public } \\
\text { transport closures, } \\
\text { lockdown ( stay at home } \\
\text { regulations and restriction } \\
\text { of movements within a } \\
\text { country) *one of the above }\end{array}$ & $\begin{array}{l}\text { - Overall reduction of } 13 \% \text { COVID-19 incidence post } \\
\text { physical distancing (Incidence rate ratios } 0.87,95 \% \\
\text { confidence interval } 0.85-0.89 \text { ) } \\
\text { - Closure of public transport was not associated with } \\
\text { additional reduction when other intervention are in } \\
\text { place } \\
\text { - School closure, workplace closure, and mass } \\
\text { gathering restriction and lockdown showed significant } \\
\text { effectiveness } \\
\text { - Early implementation of lockdown associated with } \\
\text { larger reduction of incidence compare to delayed } \\
\text { implementation of lockdown after other physical } \\
\text { interventions were in place }\end{array}$ \\
\hline $\mathrm{Ng}, 2020$ & $\begin{array}{l}\text { Age-structured } \\
\text { agent-based model/ } \\
\text { COVID-19 }\end{array}$ & $\begin{array}{l}\text { Canada/General } \\
\text { population }\end{array}$ & $\begin{array}{l}\text { A projection modeling that can } \\
\text { simulate the impact of public } \\
\text { health intervention with COVID-19 } \\
\text { transmission }\end{array}$ & $\begin{array}{l}\text { Reducing number of } \\
\text { contacts per day, (outside } \\
\text { of the household) }\end{array}$ & $\begin{array}{l}\text { - Other intervention type also studied are case } \\
\text { detection and isolation, contact tracing and } \\
\text { quarantine, and community closure (not under } \\
\text { physical distancing) } \\
\text { - Enhanced case detection and contact tracing with } \\
\text { maintained physical distancing will reduced the } \\
\text { total attack rate to } 0.2 \% \text {, the only scenario that } \\
\text { kept hospital and intensive care unit bed use under } \\
\text { capacity, prevented nearly all deaths and eliminated } \\
\text { epidemic. }\end{array}$ \\
\hline $\begin{array}{l}\text { Rubin et al., } \\
2020\end{array}$ & Cohort/COVID-19 & $\begin{array}{l}211 \text { counties/General } \\
\text { population } \\
\text { ([54.8\% of US } \\
\text { residents]) }\end{array}$ & $\begin{array}{l}\text { - Using publicly de-identified } \\
\text { daily incidence case counts } \\
\text { data (New York Times) and the } \\
\text { outcome was the estimated } \\
\text { reproduction number) } R_{\mathrm{t}} \text { of } \\
\text { COVID-19 in each county. } \\
\text { - Social distancing was measured } \\
\text { using a data set of daily cellular } \\
\text { telephone movement, provided } \\
\text { by Unacast, (comparison } \\
\text { association of social distancing } \\
\text { policies with individuals' } \\
\text { movement within a county) } \\
\text { - Percentage change in visits to } \\
\text { nonessential businesses (e.g., } \\
\text { restaurants, hair salons) within } \\
\text { each county compared with visits } \\
\text { in a 4-week baseline period }\end{array}$ & $\begin{array}{l}\text { Measured by percentage } \\
\text { change in visits to } \\
\text { non-essential business }\end{array}$ & $\begin{array}{l}\text { - Other variable that is also studied were population } \\
\text { density and temperature } \\
\text { - } 50 \% \text { decrease in visits to nonessential businesses } \\
\text { was associated with a } 45 \% \text { decrease in } \\
\text { instantaneous reproduction number (Rt) ,(95\% Cl, } \\
43 \%-49 \%) \\
\text { - } 70 \% \text { reduction in visits to nonessential business, } \\
202 \text { counties }(95.7 \%) \text { were estimated to fall below a } \\
\text { threshold Rt of } 1.0 \\
\text { - Social distancing, temperate weather, and lower } \\
\text { population density associated with a decrease in the } \\
\text { instantaneous Rt of COVID-19 } \\
\text { - Social distancing have the most substantial } \\
\text { association with a reduction in COVID-19 } \\
\text { transmission }\end{array}$ \\
\hline $\begin{array}{l}\text { Kim et al., } \\
2020\end{array}$ & $\begin{array}{l}\text { Cross sectional/ } \\
\text { COVID-19 }\end{array}$ & $\begin{array}{l}\text { South Korea } \\
\text { Workplace } \\
\text { populations (workers, } \\
\text { customers, patients } \\
\text { and students) }\end{array}$ & $\begin{array}{l}\text { Data from daily briefings } \\
\text { from the Korean Centre for } \\
\text { Disease Control (KCDC), } \\
\text { Central Disaster Management } \\
\text { Headquarters (CDMH), and local } \\
\text { governments } \\
\text { Group infection in workplace were } \\
\text { analyse pre and post introduction } \\
\text { of workplace distancing guidelines }\end{array}$ & $\begin{array}{l}\text { Consist of five } \\
\text { components which } \\
\text { are flexible working } \\
\text { system (telework, time } \\
\text { off work etc), vacation } \\
\text { system (sick leaves, } \\
\text { annual leaves), minimizing } \\
\text { meetings (avoid } \\
\text { gathering, use } \\
\text { simple meeting room } \\
\text { outside and etc) and } \\
\text { business trips (defer } \\
\text { or cancel), case } \\
\text { monitoring (suspicious } \\
\text { symptoms and } \\
\text { swift action), space } \\
\text { management (keep } 2 \mathrm{~m} \\
\text { distance between workers } \\
\text { etc) and disinfection, } \\
\text { hygiene and cleanliness }\end{array}$ & $\begin{array}{l}\text { The workplace social distancing policy with timely } \\
\text { implementation of specific guidelines was a key to } \\
\text { preventing a large outbreak of COVID-19 in Korean } \\
\text { workplaces. However, sporadic incidents of COVID-19 } \\
\text { are still ongoing, and risk assessment in vulnerable } \\
\text { workplaces should be continued }\end{array}$ \\
\hline $\begin{array}{l}\text { Morley et al., } \\
2020\end{array}$ & $\begin{array}{l}\text { Cross-sectional/ } \\
\text { COVID-19 }\end{array}$ & $\begin{array}{l}\text { County Syracuse, } \\
\text { New York with } \\
7 \text { neighboring } \\
\text { counties (Cayuga, } \\
\text { Cortland, Herkimer, } \\
\text { Madison, Oneida, } \\
\text { Oswego, and } \\
\text { Tompkins)/General } \\
\text { population }\end{array}$ & $\begin{array}{l}\text { Publicly-available mobile } \\
\text { telephone movement data, } \\
\text { tracked and graded by Unacast } \\
\text { - Data assessed use as predictors } \\
\text { of weekly average rate of } \\
\text { reproduction (Rt) value, from } \\
\text { time of first case }\end{array}$ & $\begin{array}{l}\text { Daily distance } \\
\text { Difference (Distance) of } \\
\text { travelling, daily visitation } \\
\text { difference (visitation) } \\
\text { pertaining to non essential } \\
\text { visits (retail that is non } \\
\text { grocery stores), daily } \\
\text { encounters (encounters) } \\
\text { pertaining to human } \\
\text { encounter (50 meters } \\
\text { or less }\end{array}$ & $\begin{array}{l}\text { Social distancing assessed based on these measures } \\
\text { that are publicly available (by Unacast) has a } \\
\text { significant impact on viral transmission rates }\end{array}$ \\
\hline
\end{tabular}

(Contd...) 


\section{Appendix A: (Continued)}

\begin{tabular}{|c|c|c|c|c|c|}
\hline Author/year & $\begin{array}{l}\text { Type of study/type of } \\
\text { infectious disease }\end{array}$ & Sample/population & Methodology & $\begin{array}{l}\text { Types of social distancing/ } \\
\text { physical distancing }\end{array}$ & Results \\
\hline $\begin{array}{l}\text { Hammoud } \\
\text { et al., } 2020\end{array}$ & $\begin{array}{l}\text { Cohort/HIV and other } \\
\text { STD }\end{array}$ & $\begin{array}{l}\text { Men who are gay } \\
\text { or bisexual living in } \\
\text { Australia }\end{array}$ & $\begin{array}{l}\text { Study promotion by online } \\
\text { advertisement through social } \\
\text { media, including popular gay } \\
\text { "dating" sites and apps, and } \\
\text { Facebook. Conducted between } 4^{\text {th }} \\
\text { April and } 29^{\text {th }} \text { April } 2020\end{array}$ & $\begin{array}{l}\text { Restrictions on mass } \\
\text { gatherings, closure of } \\
\text { schools, workplaces } \\
\text { and public spaces, keep } \\
\text { at least } 1.5 \mathrm{~m} \text { distance } \\
\text { from other people. Either } \\
\text { banned or strongly } \\
\text { discourages from visiting } \\
\text { sexual partners with } \\
\text { whom they did not cohabit }\end{array}$ & $\begin{array}{l}\text { Relative reduction of } 84.2 \% \text { who reported not having } \\
\text { sex with casual partners since COVID- } 19 \text { physical } \\
\text { distancing implementation. These behavioral changes } \\
\text { will likely result in short term reductions in new HIV } \\
\text { and STI dognoses }\end{array}$ \\
\hline $\begin{array}{l}\text { Kuitunen, } \\
2020\end{array}$ & $\begin{array}{l}\text { Cross-sectional/ } \\
\text { Influenza (A\&B) and } \\
\text { RSV }\end{array}$ & $\begin{array}{l}\text { Pediatric ER visits/ } \\
\text { Children in Finland }\end{array}$ & $\begin{array}{l}\text { Study was conducted in } 2 \\
\text { hospitals, and open national } \\
\text { registries for communicable } \\
\text { diseases were used. Data analyze } \\
\text { pre and post lockdown }\end{array}$ & $\begin{array}{l}\text { The term lockdown } \\
\text { were used, consist of } \\
\text { prohibition of social } \\
\text { gatherings of more than } \\
10 \text { people; universities, } \\
\text { high schools and upper } \\
\text { elementary schools were } \\
\text { closed (lower elementary } \\
\text { school classes form } \\
\text { Grade } 1 \text { to } 3 \text { were open } \\
\text { only for parents who is in } \\
\text { critical profession); day } \\
\text { care still open however } \\
\text { parent encourage to take } \\
\text { care of their children } \\
\text { at home; remote work } \\
\text { at home; residents } \\
\text { over } 70 \text { years old ordered } \\
\text { to stay at home; borders } \\
\text { of Finland were closed; } \\
\text { avoid unnecessary visits } \\
\text { to healthcare facility with } \\
\text { mild respiratory infections } \\
\text { guided to stay at home }\end{array}$ & $\begin{array}{l}\text { - Major decrease in the rate of daily median paediatric } \\
\text { ER visits in both hospitals during the nationwide } \\
\text { lockdown compared with the study period before the } \\
\text { lockdown (Mikkeli, } 19 \text { vs. } 7, P<0.001 ; \text { Kuopio, } 9 \text { vs. } \\
2,5, P<0.001 \text { ) } \\
\text { - The influenza season was shorter ( } 8 \text { weeks from } \\
\text { peak to no cases), and the weekly rate of new cases } \\
\text { decreased faster compared with the previous } 4 \\
\text { influenza seasons } \\
\text { - Similar decrease in RSV cases } \\
\text { - No paediatric cases of COVID-19 were found in } \\
\text { participating hospitals during the study period. }\end{array}$ \\
\hline Yun, 2020 & $\begin{array}{l}\text { Cross-sectional/ } \\
\text { Vaccine-Preventive } \\
\text { Disease (VPD) e.g: } \\
\text { hepatitis A, hepatitis } \\
\text { B, pertussis, mumps, } \\
\text { varicella, and invasive } \\
\text { pneumococcal disease }\end{array}$ & $\begin{array}{l}\text { Publicly available } \\
\text { aggregate data from } \\
\text { the National Notifiable } \\
\text { Disease Surveillance } \\
\text { System/Incidence of } \\
\text { VPDs in South Korea/ } \\
\text { General population }\end{array}$ & $\begin{array}{l}\text { - The baseline average monthly of } \\
\text { VPD incidence in corresponding } \\
\text { months of previous years from } \\
2015 \text { to } 2019 \text { was estimated } \\
\text { - Then comparison was made } \\
\text { with the difference in number of } \\
\text { monthly VPD incidence in } 2020\end{array}$ & $\begin{array}{l}\text { No draconian restriction } \\
\text { of movement, either } \\
\text { voluntary based or } \\
\text { administrative sanction } \\
\text { based actions. Education } \\
\text { system postponed and } \\
\text { when opened, it is open } \\
\text { step wisely. Public and } \\
\text { private places were } \\
\text { mandated to follow the } \\
\text { infection control policies } \\
\text { and guidance }\end{array}$ & $\begin{array}{l}\text { In } 2020 \text {, there were } 44 \% \text { decline for mumps, } 44 \% \\
\text { decline for varicella, } 28 \% \text { decline for pertussis, } 22 \% \\
\text { decline for IPD, } 14 \% \text { decline in incidence of hepatitis } \\
\text { A, and no change for hepatitis B incidences, compared } \\
\text { to baseline years }(2015-2019) \text {. Largest decline of total } \\
\text { VPDs was in April }(65 \%) \text { and in May ( } 67 \%) \text {, during the } \\
\text { intensified social distancing measures. In the setting of } \\
\text { sustained vaccination coverage, social distancing may } \\
\text { provide additional public health benefit in controlling } \\
\text { the VPDs }\end{array}$ \\
\hline
\end{tabular}

Appendix B: The details of mixed method appraisal tool assessment

\begin{tabular}{|c|c|c|c|c|c|c|c|c|}
\hline Author & Type of study & $\begin{array}{l}\text { MMAT } \\
\text { scores }\end{array}$ & $\begin{array}{l}1.1 \\
\text { Is the qualitative } \\
\text { approach } \\
\text { appropriate to } \\
\text { answer the research } \\
\text { question? }\end{array}$ & $\begin{array}{l}1.2 \\
\text { Are the qualitative } \\
\text { data collection } \\
\text { methods adequate to } \\
\text { address the research } \\
\text { question? }\end{array}$ & $\begin{array}{l}1.3 \\
\text { Are the findings } \\
\text { adequately derived } \\
\text { from the data? }\end{array}$ & $\begin{array}{l}1.4 \\
\text { Is the } \\
\text { interpretation } \\
\text { of results } \\
\text { sufficiently } \\
\text { substantiated } \\
\text { by data? }\end{array}$ & $\begin{array}{l}1.5 \\
\text { Is there coherence } \\
\text { between qualitative } \\
\text { data sources, } \\
\text { collection, analysis } \\
\text { and interpretation? }\end{array}$ & $\begin{array}{l}\text { Outcome } \\
\text { yes/no }\end{array}$ \\
\hline Islam et al., 2020 & Quantitative non-randomised & $90 \%$ & Yes & Yes & Yes. Not complete & Yes & Yes & $\mathrm{Y}$ \\
\hline $\mathrm{Ng}, 2020$ & Qualitative & $70 \%$ & Yes & Yes & Yes. Not complete & Yes & Unsure & $\mathrm{Y}$ \\
\hline Rubin et al., 2020 & Quantitative non-randomized & $100 \%$ & Yes & Yes & Yes & Yes & Yes & $\mathrm{Y}$ \\
\hline Kim et al., 2020 & Quantitative non-randomized & $100 \%$ & Yes & Yes & Yes & Yes & Yes & $\mathrm{Y}$ \\
\hline $\begin{array}{l}\text { Morley et al., } \\
2020\end{array}$ & Quantitative non-randomized & $80 \%$ & Yes & Yes & Yes & Yes & Unsure & Y \\
\hline $\begin{array}{l}\text { Hammoud et al., } \\
2020\end{array}$ & Quantitative non-randomized & $100 \%$ & Yes & Yes & Yes & Yes & Yes & Y \\
\hline Kuitunen, 2020 & Quantitative non-randomized & $100 \%$ & Yes & Yes & Yes & Yes & Yes & $\mathrm{Y}$ \\
\hline Yun, 2020 & Quantitative non-randomized & $70 \%$ & Yes & Yes. Not complete & Yes & Yes & unsure & $\mathrm{Y}$ \\
\hline
\end{tabular}

